\title{
Mitre e a formulação de uma história nacional para a Argentina
}

TULIO HALPERIN DONGHI

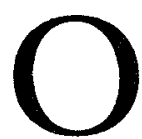

general Bartolomé Mitre que - como primeiro presidente, em 1862-68, de uma Argentina finalmente unificada, logo após o longo hiato provocado pela dissolução do Estado revolucionário em 1820 -, talvez seja o mais qualificado para ser reconhecido no papel de pai da Argentina moderna, paradoxalmente, é lembrado com freqüência no papel mais modesto de fundador de uma nova historiografia argentina, caracterizada por uma seriedade erudita e uma objetividade científica até então inexistentes.

Examinada mais atentamente, a passagem da crônica facciosa para a história rigorosa que se deve a Mitre surge como tributo de outra mudança não menos decisiva: a multiplicidade de sujeitos individuais $\mathrm{e}$ coletivos que até então preenchiam a cena histórica - desde as facçóes esconjuradas ou enaltecidas nas toscas reconstruçóes inspiradas pela paixão política até as ideologias ou os complexos sócio-culturais antagônicos entre si, evocados nas interpretaçôes mais ambiciosas de Echeverría ou Sarmiento - é decididamente deixada de lado em benefício de uma majestosa presença central: agora a Nação é elevada a protagonista única do processo histórico. É precisamente a postulaçáo dessa temática, que subordina todos os que pululavam até então no cenário da história argentina, que permitirá a Mitre, em sua própria opinião, manter frente a eles a distância requerida para atingir uma reconstruçáo histórica dotada de validade científica.

O entrelaçamento entre a exigência erudita e a ruptura do elo com qualquer um desses aspectos parciais está explicitamente declarado na caracterização do projeto histórico que Mitre opóe ao de seu grande rival, Vicente Fidel López, na polêmica em que vão se confrontar. Para López, a decisão de usar a memória coletiva do patriciado portenho como fonte histórica privilegiada, de cuja perspectiva ele se torna eco, associa-se ao reconhecimento desse grupo como o protagonista do processo histórico: o resultado é uma narração que não consegue ocupar 
plenamente o âmbito nacional a que seu autor aspira; antes de ser da República Argentina, sua história é a dessa que López chama de burguesia liberal portenha; sem dúvida, por essa razão López nunca vai realizar seu desejo de perpetuá-la além do ano de 1829 , ano em que a ascensáo de Rosas consuma a bancarrota definitiva do grupo dirigente que conduziu a revolução emancipadora para logo desviar o rumo, sob a influência de Rivadavia.

A recusa em identificar-se com os pontos de vista de qualquer um dos atores individuais e coletivos que dominaram a cena histórica não supõe - Mitre vai acentuar energicamente - a renúncia a estruturar a história a partir de um ponto de vista preciso. Quando López opóe à opçáo erudita de Mitre sua suposta preferência por uma história filosófica, a áspera resposta deste último é que, na obra de seu rival, a carência erudita se estende à carência filosófica. A essa dupla carência Mitre opóe o domínio que se vangloria de ter obtido em ambos os campos, graças ao auxílio do método indutivo, que lhe permite chegar a conclusóes gerais a partir da acumulação de conhecimentos empíricos devidamente controlados. Se esta última reivindicação é discutível (assim que se examina o modo de historiar de Mitre, torna-se evidente que suas supostas conclusóes sáo pouco merecedoras desse nome: sáo muito mais as premissas que dirigem seu esforço para estruturar em um todo coerente o amontoado de dados reunidos por ele), isso náo impede que essas premissas disfarçadas de conclusões substituam com êxito, com a função de dar sentido aos fatos evocados, as convicçóes facciosas de que López ainda é tributário, ou os pontos de vista extremamente polarizados de Echeverría ou Sarmiento.

Essas premissas são as mesmas da historiografia liberal-nacionalista que floresceu na Europa da Restauração e do paradoxal renascimento liberal que a sucedeu; Mitre reconhece de bom grado sua dívida para com esse modelo ultramarino. Porém, verifica-se aqui algo mais que a adoção de um modelo prestigiado: essa tradição historiográfica encontra o terreno adequado para revolucionar suas intuiçóes essenciais sobre os fatos históricos que se propóe a arrolar.

O que leva Mitre a propor uma história argentina, pela primeira vez, realmente a história de uma Nação? Em primeiro lugar, a conviç̧âo de que - desde o começo da conquista espanhola - o rio da Prata tem sido palco do nascimento e da consolidaçáo de uma sociedade cujos traços peculiares podem ser reconhecidos já em embriáo no ponto de partida, e nasce com admirável vigor expansivo permitindo-lhe vencer, em seu poderoso impulso para adiante, os obstáculos encontrados em 


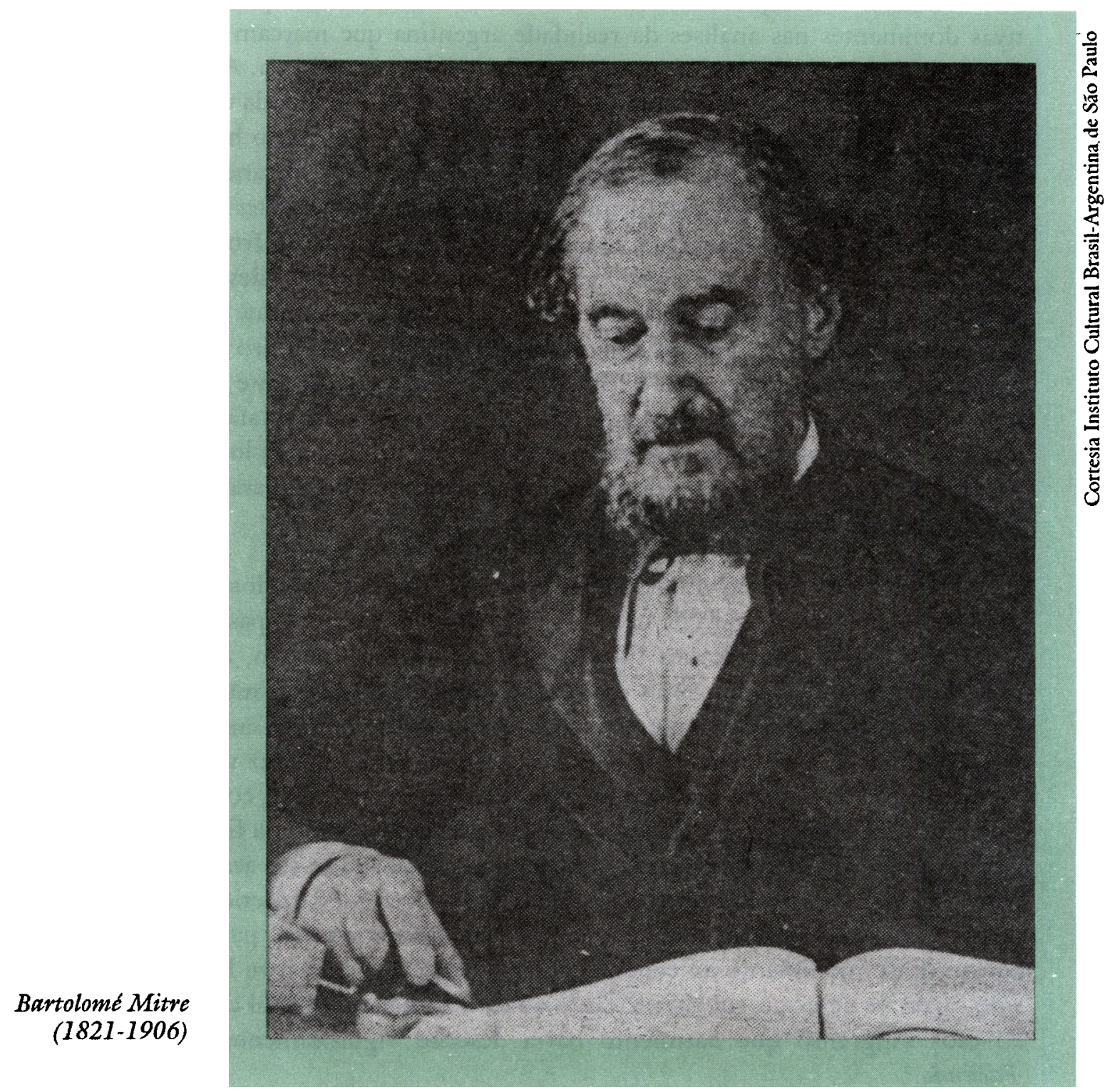

seu caminho. Em segundo lugar, a conviç̧áo de que esse sujeito coletivo só vai alcançar sua plena realizaçāo histórica na figura da Nação, e através do esforço para constituir-se no marco institucional do Estado liberal. Isso faz com que - apesar da profunda atenção dedicada por Mitre às transformaçóes econômicas e culturais condicionantes do processo histórico argentino - sua história seja sobretudo política, à medida em que vai centrar-se nos problemas da constituição e progressiva institucionalização do Estado, concomitantemente ao surgimento e consolidaçáo de formas de autoridade especificamente políticas. 
As duas convicçóes afastam Mitre do mesmo modo das perspectivas dominantes nas análises da realidade argentina que marcam presença no momento no qual se começa a refletir sobre esta última. As de Sarmiento e Alberdi, divergentes em muitos aspectos, sem dúvida coincidem em negar que a Argentina esteja predestinada a um rumo histórico constantemente ascendente, já perceptível, mesmo considerando as aparências enganosas, em seus primeiros passos pouco brilhantes. Em contraposição, ambos coincidem em alertar contra o perigo de frustração total que só poderia ser evitado se os argentinos decidissem desviarse do rumo histórico percorrido até entáo, para ingressar no que cada um deles propõe. $\mathrm{E}$ - embora ambos considerem que, um futuro mais imediato, tudo dependeria do desfecho de uma luta essencialmente política, na qual o que estaria em jogo seria o controle do poder estatal -, ambos atribuem à esfera da política e do Estado um valor apenas instrumental, a serviço de objetivos de transformação sócio-cultural para Sarmiento, e sócio-econômica para Alberdi.

Mitre substitui essa visáo obcecada pelo risco do fracasso, dos seus grandes predecessores, pela de um processo histórico em que o passado já contém a promessa de um futuro brilhante. Nessa imagem, a ser revelada em suas grandes obras históricas, vemos refletir-se o mesmo otimismo quanto ao fundamental, que permite ao Mitre político enfrentar serenamente quase todos os reveses e curvar-se sem qualquer sentimento de derrota ante as mais graves transaçóes; esse otimismo, constitutivo do traço básico tanto da personalidade intelectual como da figura pública de Mitre, não poderia ser mais radical. Todavia, se ele acabou por obter a aprovaçáo de seus compatriotas, foi por refletir a experiência dos setores cada vez mais amplos que, na sociedade argentina, participavam desse movimento ascendente, cuja presença secreta Mitre havia sido capaz de detectar, subjacente tanto ao estancamento colonial como ao caos sangrento que Sarmiento havia descrito vigorosamente em Facundo.

Essa história em contínuo avanço na direção de novos ápices, que Mitre apresenta como a da Naçáo que surge através dela para a vida, e finalmente é compartilhada por todos os que contam com esse marco inicial criado dessa forma, começou por refletir uma visão arraigada em uma experiência mais regional que nacional: é a história que pode ser vista de Buenos Aires, a grande beneficiária da abertura para o Atlântico, realizada pela criaçáo do vice-reinado do rio da Prata e ampliada em suas conseqüências pela liberalização comercial que - decretada pelo último vice-rei - iria permanecer na própria base da ordem pós-revolucionária, tanto em meio às convulsóes da guerra civil, como sob o domínio férreo 
de Rosas. Nas décadas que se seguiram à emancipação, um formidável processo expansivo permitiu a Buenos Aires reunir um terço da população das províncias argentinas e mais de dois terços de suas riquezas. Conforme ensina o texto elegíaco Recuerdos de Provincia de Sarmiento, para a província de San Juan, onde ele nasceu, enquanto a nova ordem trouxe apenas calamidades, e ainda que para a Tucumán de Alberdi tenha trazido inovaçóes menos catastróficas, porém quase todas negativas, a trajetória da província portenha nessas mesmas décadas inspira mais ufanismo que preocupação.

Antes de cair na versão da história argentina a ser articulada por Mitre, essa imagem da experiência argentina já inspirava a negaçáo de todos os interlocutores portenhos de Sarmiento para aceitar a visão épica e trágica que tornava essa história um conflito entre civilização urbana e barbárie pastoril. As reticências ante essa outra versão que ameaçava tornar-se canônica exibiam-se e se ocultavam ao mesmo tempo, nas notas de Valentín Alsina em Facundo: depois de aprovar por pura cortesia ("creio que há algo de exato no fundo dessa idéia, sem que, em minha humilde opinião, o seja inteiramente" ) (1), Alsina se apressava em solapá-lo, através do que apresentava como um esforço amistoso para eliminar erros de informaçáo, e era, a rigor, uma tentativa de explicar os mesmos fatos que Sarmiento interpretava nessa explicação, prescindindo dela. É particularmente reveladora a nota 20 , limitada ostensivamente a corrigir o erro de colocar Rosas entrando em Buenos Aires em 1820 à frente do corpo de Colorados de las Conchas; tratava-se, na verdade, - lembra Alsina - do quinto regimento de milícias, que também se vestia de vermelho, "porém essa cor, na época, era indiferente $\mathrm{e}$ acidental, sem nenhum significado, e usada por outros. Os colorados de las Conchas eram outro corpo muito diferente [...] Já muitos anos antes de 1820 vestiam-se de vermelho. Foi o melhor e mais valente corpo de milícias que Buenos Aires teve... o único corpo de milícias... que fez a campanha do Brasil: daí a grande amizade de Lavalle com seu coronel, e daí que este também estivesse entre os do [golpe militar unitário de] $1^{\circ}$ de dezembro. Seu coronel era Vilela, que depois foi surpreendido em San Calá, e assassinado por Oribe em Tucumán, com Avellaneda e outros" (2).

O que parece ser uma correção de detalhes, contém, implicitamente, uma recusa tanto do método como das conclusóes de Facundo. $\mathrm{Na}$ hermenêutica sarmientina a barbárie é um conjunto com sentido coerente, no qual nada foi jogado ao acaso; ao sugerir que a adoçáo do vermelho como cor emblemática dessa barbárie pudesse ser bastante acidental para que coincidissem nela um porta-estandarte e um mártir 
da civilizaçáo, Alsina deixa discretamente de lado os pressupostos básicos sobre os quais se construiu Facundo. Contra a férrea legalidade que governa o universo sarmientino, Alsina prefere ressaltar o papel do erro humano, e até mesmo do acaso: são as falhas de Rivadavia, de Dorrego, de Lavalle, que - antecipando-se à captura acidental do general Paz, o admirável chefe militar e indomável adversário de Rosas - prepararam o triunfo totalmente desnecessário deste último. A resistência aos sistemas que partem de uma idéia-mãe e buscam na história apenas exemplos que a justifiquem torna-se necessária a Alsina, para recusar a imagem de Rosas como a esfinge que guarda o segredo do destino argentino com que se inicia Facundo: longe de ser uma figura-chave, o homem que tem o pode de manter Sarmiento e Alsina no desterro é apenas o produto circunstancial de um acidente histórico.

Porém a resistência portenha à visão sarmientina não decorre apenas do desejo de reivindicar o que a marcha da história tem de circunstancial, por parte daqueles que percebem melhor que Sarmiento que seu retrato apocalíptico de um país dividido em dois hemisférios em luta deixa muito pouco espaço para a esperança: Buenos Aires, cuja brilhante civilizaçăo urbana, expressa politicamente no governo que teve Rivadavia como inspirador, e que Sarmiento náo se cansa de exaltar, tornou-se possível pela expansáo vertiginosa de sua economia pastoril, negando-se a se identificar no retrato da barbárie pastoril que lhe propóe Sarmiento. E tem para isso bons motivos: os traços esboçados por Sarmiento, com admiraçáo horrorizada, como definidores do hemisfério de sombras que é a barbárie, sáo cultivados sem pudor pelos corifeus dessa geraçáo portenha de 1837, sob cujo influxo o natural de San Juan se abriu para o mundo das idéias; Echeverría, que trouxe de Paris as novidades literárias e ideológicas com que essa geração iria se nutrir, orgulhava-se de sua destreza com o violáo, que, nas mãos do cantor garícho era apresentado em Facundo como o instrumento artístico por excelência do mundo bárbaro; por sua vez, a pálida poesia do literato mais elegante dessa geração, Juan María Gutiérrez, alcançava sua nota mais vigorosa ao cantar seu cavalo, ao qual parecia estar ligado (como aos bárbaros evocados por Sarmiento) por sentimentos mais efusivos que os refletidos nas evocaçóes de amadas excessivamente fantasmagóricas (3); ainda mais ilustrativo é o contraste entre a passagem horrorizada de Facundo, que procura, nos entretenimento gaúchos, os traços infinitamente repulsivos da barbárie e o poema juvenil (4) no qual Mitre enaltece, no jogo de pólo, o esporte em que se destacam as virtudes de uma raça extremamente livre e viril.

A recusa desses pontos de vista problemáticos do curso da histöria 
argentina, que Alsina havia atribuído ao papel decisivo do acaso, em Mitre, ao contrário, vai desembocar na postulação de um curso histórico oposto, que, desde as humildes origens rio-platenses, nunca se desviou de uma linha ascendente destinada a continuar indefinidamente rumo ao futuro.

A certeza de que a Argentina tem aliança com o futuro, subentendida na construçáo histórica de Mitre, é também o resultado de uma visão da Argentina a partir de Buenos Aires, agora a partir da Buenos Aires pós-Rosas, que acelera ainda mais o ritmo de sua expansáo econômica enquanto faz de sua derrota nos campos de Caseros a promessa logo cumprida de seu triunfo final.

É a Buenos Aires que deslumbrou Sarmiento em 1855, quando três anos após a derrocada de Rosas - veio radicar-se na cidade que, de longe, havia imaginado devastada por um quarto de século de opressão, sob um regime inimigo de todo progresso. Na que foi capital da tirania, e agora é capital de uma província em secessáo, cujo governo nenhuma potência se decide a reconhecer, e cujo futuro político não poderia ser mais incerto, descobre, ao contrário, uma sociedade dinâmica e vibrante, na qual a prosperidade das elites, que lotam teatros inteiros com suas roupas luxuosas, se complementa com a prosperidade mais importante, para Sarmiento, de suas classes populares (" năo encontrei povo, chusma, plebe, maltrapilhos... o traje é o mesmo para todas as classes, ou, mais exatamente, não há classes" ). Enquanto que para a imaginada Buenos Aires de Facundo o único modo de evitar uma ruína irreversível era a instauração de uma ordem nova a partir das origens, nessa Buenos Aires tão diferente, que seus olhos revelam enfim a Sarmiento, essa ruína era simplesmente impossível: "com a guerra, a paz, a união ou o deslocamento, este país caminha, caminhará" (5).

A visão histórica de Mitre vai nutrir-se dessa fé coletiva, à qual, por sua vez, oferece uma formulaçáo precisa. Esta se destaca pela primeira vez em 1868, na evocação das origens, que abre a segunda edição da História de Belgrano, na qual a biografia incluída em 1857 na Galeria de Celebridades Argentinas e publicada em volume separado no ano seguinte oferece o esqueleto para um livro que quer ser "ao mesmo tempo a vida de um homem e a história de uma época", e que não sofrerá transformaçóes essenciais ao ser publicado novamente em versão definitiva, em 1887.

Essa evocação das origens argentinas é, ao mesmo tempo, uma reivindicaçáo da excepcionalidade argentina no âmbito de uma América Espanhola que surgiu sob o signo do feudalismo, apresentando seu per- 
fil mais definido no México e no Peru. Lá o poder espanhol, implantado "em um império conquistado e explorando o trabalho de uma raça dominada, impunha-se como o feudalismo europeu, distribuía entre os conquistadores o território e seus habitantes, tendo em vista exclusivamente a exploraçáo dos metais preciosos" (6).

Nada disso ocorreu no rio da Prata: "batizada com um nome enganoso [...] todo o seu capital se compunha de planícies cobertas de ervas daninhas [...] e uma agricultura primitiva que atendia apenas às necessidade prementes dos indígenas". "Assim nasceu e cresceu a colonizaçáo argentina, em meio à fome e à miséria [...] oferecendo o único exemplo, na América do Sul, de uma sociabilidade decorrente do trabalho produtivo". A penúria foi assim uma bênção secreta, à medida em que salvou as comarcas rioplatenses da sina do México e do Peru, refugos de uma "semicivilizaçáo organicamente fraca", em cujo "tronco podre" os conquistadores enxertaram uma versão já arcaica da civilização européia. Ante um Peru dividido entre uma maioria indígena que sobrevive "sem ser assimilada pelos conquistadores", no rio da Prata os mestiços "eram considerados como espanhóis de raça pura e constituíam a força da colônia [...] com eles se fundavam as novas cidades [...] eles tomavam parte nas agitaçóes da vida pública, inoculando na sociedade um espírito novo. Em seu seio nasciam os historiadores da colônia, os governantes destinados a dirigi-la, os cidadáos do embrionário município, e uma individualidade marcada por um certo estigma de independência rústica, que pressagiava o tipo de um povo novo, com todos os seus defeitos e qualidades". Em lugar de uma sociedade dividida horizontalmente por fronteiras étnicas entre conquistadores e conquistados, uma precocemente unificada em torno de "uma nova raça destinada a ser a dominante no país"; uma sociedade em que, além do mais, a pobreza universal atenuava as desigualdades econômicas: "como, na verdade, não havia pobres nem ricos, sendo todos mais ou menos pobres, resultava de tudo isso uma espécie de igualdade ou equilíbrio social, que impregnava desde muito cedo os princípios de uma sociedade livre, no sentido da espontaneidade humana" (7).

A excepcionalidade rioplatense tinha tanto raízes européias como americanas. Diferentemente de Cortés e Pizzarro, meros "homens de ação" à frente de "aventureiros intrépidos ávidos e vorazes", dedicados à tarefa de submeter e explorar os povos vencidos, os espanhóis que chegaram ao Prata foram, mais que conquistadores, "verdadeiros imigrantes, recrutados nas classes e nos lugares mais adiantados da Espanha... nascidos e criados em comarcas trabalhadoras, em portos marítimos... em cidades... traziam na cabeça outras noçóes práticas e outras 
luzes, que faltavam aos habitantes... de Extremadura, da Galícia ou de Castela, a Velha, que deram seu contingente à colonização do Peru, na qual seu caudilho mais importante náo sabia sequer escrever o próprio nome" (8).

Uma sucessão de pinceladas nada sutis traça assim o perfil de uma sociedade mais moderna e genericamente européia que neofeudal, e especificamente espanhola. Porém essas virtudes de origem năo bastavam para assegurar a esse embrião da Europa implantado no rio da Prata o grande destino a que elas lhe davam direito. Ass virtudes devia somarse a influência, que se faria sentir com intensidade crescente a partir desse humilde ponto de partida, da constituiçäo geográfica da comarca, cujas "planícies cobertas de ervas daninhas" ocultavam uma das mais ricas pradarias do planeta: "O pampa imenso e contínuo dava sua unidade ao território. O estuário do Prata centralizava todas as suas comunicaçóes. Os prados naturais convidavam seus habitantes ao trabalho pastoril. Seu vasto litoral o punha em contato com o resto do mundo por meio da navegação fluvial e marítima. Seu clima saudável e temperado tornava mais agradável a vida e mais produtivo o trabalho. Era, pois, um território preparado para o gado, constituído para prosperar através do comércio, e predestinado a povoar-se pela aclimatação de todas as raças da terra" (9).

Embora Mitre não deixe de mencionar, entre as bênçãos naturais que confirmam essa promessa de um grande destino, os "prados naturais [que] convidavam seus habitantes ao trabalho pastoril", a reivindicaçáo de um papel positivo para o gado, relegado por Sarmiento ao hemisfério da barbárie, era apenas sugerida de passagem. Sem dúvida, ela é essencial à sua argumentação, e quase contemporaneamente à publicaçăo desta segunda ediçáo da História de Belgrano, Mitre a apresenta de modo mais explícito no discurso que profere em Chivilcoy, onde Sarmiento, já eleito para sucedê-lo na presidência, prometeu três semanas antes refazer toda a planície do pampa conforme o modelo dessa quase exclusiva colônia agrícola na campanha portenha. Para justificar seu ceticismo frente a essa proposta, na qual se reflete a dogmática condenação que formulam contra o país plasmado por três séculos de história aqueles que se julgam sábios, Mitre invoca a instintiva sabedoria popular, à qual oferece os argumentos que esta é incapaz de articular: ou seja, que a província náo só deve sua existência, mais ainda que aos homens, às vacas que se adiantaram àqueles avançando no pampa deserto, como, no presente, o gado torna possível a consolidação, às margens do Prata, de uma sociedade mais próspera, menos desigual e - para resumir - mais civilizada que a do Chile agrícola (10). 
Portanto, não é de surpreender que os avanços a partir dessas modestas origens náo pressuponham alguma soluçăo de continuidade mas, ao contrário, prossigam na rota originalmente traçada. A experiência argentina entra em uma nova e decisiva etapa quando o ritmo de expansão dessa sociedade em contínuo crescimento ameaça ver-se refreado pelo opressivo pacto colonial, que lhe veda essa necessária abertura para o mundo, para poder prosseguir em sua marcha ascendente. Começa entáo o processo que vai culminar com a guerra da independência, na qual vai forjar-se a nacionalidade. Essa transformação de uma sociedade em Nação será, a rigor, o tema da História de Belgrano, na qual Mitre não atribui ao herói um papel de protagonista constante no processo. O que o torna mais adequado do que qualquer outra personagem, entre seus contemporâneos, para ocupar o lugar central na narrativa é sua condição - na verdade excepcional no conjunto da elite portenha que assumirá as rédeas do processo revolucionário - de participante significativo nas etapas sucessivas do processo que iria desembocar na ruptura revolucionária: primeiro a serviço da monarquia ilustrada e introdutor no rio da Prata dessa nova ciência que é a economia política, papel que ele desempenhou promovendo a tomada de consciência da região a partir do conflito de interesses que iria levar inevitavelmente ao choque com o regime colonial, e depois com mais abnegaçáo que sorte, a serviço da causa revolucionária no campo político e militar.

Ao entrar na etapa revolucionária, Mitre volta à problemática especificamente política que o instigava desde o começo de sua carreira intelectual. Ela se centrava em dois temas intimamente ligados, sem dúvida, porém ainda assim distintos: um processo - que ele vê como já contemporâneo do nascimento da política como área autônoma de experiência coletiva - através do qual se consolida a liderança pessoal de determinados indivíduos, e outro mais lento e contrastivo, graças ao qual essa liderança primeiro rompe com o marco institucional que a revolução não conseguiu renovar tão radicalmente quanto teria sido necessário, e, por fim, - através de intermináveis vicissitudes muitas vezes sangrentas - acaba sendo mediado e absorvido pelo império impessoal de outras instituições mais aptas a expressar as aspiraçōes coletivas que desencadearam o processo revolucionário.

O primeiro desses tópicos já foi apontado pela geração de 1837 , da qual também Mitre é tributário, a partir das reflexóes de Cousin sobre o papel dos homens representativos, recolhidas por Echeverría no Credo de la joven generación argentina, de 1838 , e invocadas no mesmo ano de 1838 por Alberdi, como argumento legitimador do poder de 
Rosas em seu Fragmento preliminar ao estudo do Direito, para escândalo de alguns de seus futuros companheiros na luta anti-Rosas. Os homens de 1837, como agora Mitre, preocupavam-se menos em entender e legitimar o fenômeno da liderança política que em justificar o fato decepcionante de, no rio da Prata, essa liderança só recaira por pouco tempo sobre aqueles que estavam melhor preparados para exercê-la e, entretanto, logo eram repudiados em suas pretensóes de desempenharem o papel de dirigentes. Tratava-se, em suma, de entender as origens do que já se chamava de caudilhismo, e Mitre dedicou seu primeiro ensaio historiográfico a desenvolvê-las através da figura de José Artigas, o chefe da revoluçáo da Banda Oriental que, em 1815, liderou um sistema político rival daquele institucionalizado de modo mais maduro, que governava Buenos Aires desde 1810.

Mitre tinha excelentes razóes para escolher Artigas; não só havia acompanhado o pai no desterro para a antiga Banda Oriental, agora República Oriental do Uruguai, como nela estavam o seu próprio avô, e o pai de seu biografado, destacando-se como chefe de uma das famílias fundadoras de Montevidéu. Ainda que o êxito limitado do avô de Mitre como empresário rural tivesse contribuído para que seu filho, e pai do futuro homem público, seguisse uma carreira administrativa que o levou de volta a Buenos Aires, cidade onde o primeiro Mitre se havia estabelecido no século XVII (e Bartolomé nasceu em 1821), desde o início da década de 1830 o triunfo de Rosas o levou de volta a sua nativa Montevidéu, onde passou para o serviço da recém-criada república independente. E o sogro de Mitre é o general Vedia, descendente de uma linhagem de oficiais peninsulares arraigada no Prata desde o século XVIII, que vinha servindo na Banda Oriental primeiro ao rei, mais tarde a Buenos Aires e agora a Montevidéu, e que, ao serviço da segunda, teve oportunidade de entrevistas e contatos com Artigas, que o deixaram extremamente impressionado.

Embora ignoremos a data exata da composição dessa biografia destinada a permanecer inédita por um século - ela é anterior a 1843 (11), quando a imagem francamente negativa da época artiguista, em que haviam coincidido, logo depois de 1820 , todas as facções rioplatenses, sem dúvida havia perdido bastante de sua virulência, mas ainda não havia sido negada. Então poder-se-ia esperar - sobretudo da pena de um jovem exilado em Montevidéu por outro caudilho - um retrato em que predominassem as cores sombrias e conclusóes que ressaltassem os efeitos desoladores da ação de Artigas.

Contudo, isso quase não se encontra no relato de Mitre. Sem dúvida o fato em parte se deve a que, entre suas motivaçóes, a de solucionar 
um problema histórico parece ter pesado menos que a de adestrar-se na narrativa histórica: o Artigas parece ser, acima de tudo, o exercício de um aprendiz de historiador, que em seu Diário mostra-se muito atento aos problemas colocados pela escritura da história.

Ainda assim, é possível rastrear no Artigas uma visão precisa das origens do caudilhismo; visão que tem muito em comum com a que será proposta em Facundo, porém se nega a adotar o tom sombrio do texto sarmientino. Sem dúvida, alguns desses elementos comuns devem-se ao fato de Sarmiento e Mitre serem tributários da visão do caudilho alimentada pelo despeito de seus derrotados rivais da elite letrada: é o que ocorre quando rastreiam, na precoce rebeliáo contra a autoridade paterna, nutrida na subversão a qualquer disciplina, a primeira manifestação das tendências que logo irão se evidenciar na vida pública tanto de Artigas quanto de Quiroga. Aqui já se percebe, ao mesmo tempo que uma diferença (o julgamento psicológico-moral, sobre esses episódios imaturos, francamente negativo em Sarmiento, e muito menos em Mitre), uma semelhança talvez mais significativa: Sarmiento ainda vê nessa indisciplina a expressão de ambiçōes que, em um ambiente histórico mais propício, teriam podido propiciar para Quiroga uma glória mais autêntica que a derivada de suas deploráveis façanhas; se houvesse nascido na França, e não em um remoto rincão colonial assediado pela barbárie, Facundo poderia ter-se transformado em um dos mais valentes marechais napoleônicos...

Assim como sua delimitaçáo ao hemisfério da barbárie fecha, para Quiroga, esse caminho alternativo, é o primitivismo do contexto no qual se desenvolve a carreira de Artigas que perverte e desvaloriza as façanhas que a pontilham. Essa semelhança oculta novamente, sem dúvida, uma diferença ainda mais importante entre a perspectiva de Mitre e a de Sarmiento: o primitivismo do estilo de liderança de Artigas provém de sua situação determinada na etapa inicial.de um caminho ascendente, em que a democracia se apresenta "pura e sem abstraçóes, representada pela força muscular" (12). Essa menção fugaz reflete nesse escrito juvenil a gravitaçăo da imagem do processo histórico que se revelará plenamente um quarto de século mais tarde, tanto na História de Belgrano como no discurso de Chivilcoy: neste último, em expressão brincalhona que revela conviç̧ằo muito séria, redefine o que Sarmiento chamava de barbárie como "a civilização pastoril marchando em quatro patas".

Embora algumas das formulaçóes incluídas em Facundo pudessem ter oferecido o fio condutor para uma visáo análoga à de Mitre (caso da apresentaçāo do conflito que consome a Argentina como resultado inevitável da justaposição de batalhas que remontam ao século XII 
e cidades que participam da civilização do XIX (13)), a barbárie não é para Sarmiento a primeira etapa na marcha ascendente da civilizaçăo, mas sua antítese. O que define a visáo de Mitre, porém, não é apenas uma confiança genérica na vocaçáo para o progresso que caracteriza o processo histórico argentino; esse progresso ocorre, para ele, principalmente no plano político e pode ser medido pelos avanços da institucionalização do poder.

Nessa conviç̧áo talvez se possa ver o indício de outra das forças que garantiram o êxito histórico de Buenos Aires, que costuma ser salientado de modo menos complacente que os dons de uma natureza pródiga: é a criaçáo, por vontade régia, de um grande centro administrativo e militar no novo marco brindado pela reorganização imperial dos tardios anos setecentos. Em seu Rosas y su tiempo (14), José María Ramos Mejía havia pesquisado a chave da personalidade de Rosas em uma dupla herança sociológica: à linhagem materna dos López de Osornio deviam-se os traços próprios da linhagem de um grande proprietário dos pampas, senhor de homens, terras e gado; à paterna, dos Ortiz de Rosas, a forma mentis cunhada no cadinho da tradiçáo burocrática espanhola. Como só poderia acontecer, o perspicaz psiquiatra e criminologista, acreditando oferecer explicações psicológicas, oferecia outras, muito valiosas para a história: mais que uma herança genética, a que Ramos Mejía descobre em Rosas é a experiência coletiva de sua cidade e de sua região natal.

Essa experiência deve ter também atingido Mitre: seu pai já havia desenvolvido sua vida nesse meio burocrático, e ele mesmo parece ter-se preparado desde a adolescência para o serviço do Estado; aos catorze anos, sem dúvida tendo em vista uma carreira nas repartiçóes da fazenda, ingressava na escola mercantil do Consulado de Montevidéu; no ano seguinte, seu pai perdia o cargo de tesoureiro geral da República e em 1837 Mitre ingressava na escola de artilharia da Academia Militar de Montevidéu, da qual saiu como alferes em 1839. Diferentemente de Sarmiento, arrastado para a milícia pela voragem da guerra civil, para Mitre abria-se desde o início uma carreira profissional, em todos os sentidos do termo: náo só supunha o ingresso com vocaçáo permanente para uma estrutura institucional bem-consolidada, como a aquisição de uma competência específica pela via da aprendizagem formal (em 1844, enquanto servia às forças que defendiam Montevidéu sitiada, iria redigir uma Instrucción práctica de artillería, para el uso de los señores oficiales de artilleria de la linea de fortificación (15).

No âmbito militar, ambos os aspectos - necessidade de compe- 
tência específica e de uma institucionalização rigorosa - talvez apareçam mais intimamente relacionados que em qualquer outro. Mitre ressaltará igualmente a ambos, em dois artigos para a imprensa, em fevereiro de 1846, La montonera y la guerra regular e Necesidad de la disciplina en las repriblicas (16). Como Alsina, aqui reafirma, em oposiçáo a Sarmiento, que a vitória dos exércitos regulares contra os guerrilheiros recrutados pelos caudilhos oferece um desfecho mais freqüente que o oposto, nos conflitos entre ambos. Entretanto, acima dessa conclusão solidária com a otimista visão portenha do futuro argentino, esses textos constituem um arrazoado em favor da profissionalizaçáo e institucionalizaçáo com fins legítimos em si mesmos, e náo só como instrumento de vitória, no que já vemos destacar-se um motivo que será central na visão histórica de Mitre.

Entretanto, essa institucionalizaçáo náo pode seguir as linhas da que foi implantada no Prata pela monarquia ilustrada: também nesse ponto Mitre se afasta de López, para quem Buenos Aires nunca voltou a ser táo bem governada como nos tempos felizes de D. Carlos III. A revoluçăo quebrou irremediavelmente a couraça monárquica e imperial que ameaçava sufocar o crescimento dessa sociedade instintivamente igualitária e marcada desde as origens por uma democracia própria, a do rio da Prata. E essa revolução alcança seu momento culminante não em 1810, mas em 1820, quando os caudilhos destroem o Estado herdeiro da administraçáo do vice-reinado que, de Buenos Aires, conduziu a luta pela independência durante dez anos; só então, assegura Mitre, a revolução política se torna revolução social, é incorporada finalmente pela sociedade, e graças a ela a Argentina assume de modo irreversível essa vocaçáo democrática que, sem que soubesse, havia sido a sua desde as origens. Desse modo, o que parecia para López uma catástrofe irreparável, pela qual ele culpava San Martín por ter-se negado a abandonar a luta pela libertação do Peru para combater os caudilhos rioplatenses, oferecia para Mitre a consumação da revolução emancipadora (17).

Porém essa democracia continua sendo inorgdnica; a tarefa que falta cumprir é a de organizá-la, e deve ser exatamente esse o programa para a Argentina pós-Rosas. Essa organizaçáo tem uma única forma possível: a da república democrática, porém esta não é - em contraposiçâo ao pensamento de Bello e ainda de Sarmiento e Alberdi - um enxerto exótico que só pode se enraizar no inóspito solo hispano-americano após uma difícil etapa de penetração ideológica e transformaçáo social; ao adotá-la, a Argentina só terá de envolver-se na roupagem institucional, para a qual sua vocaçáo a tem guiado desde as remotas origens. Entretanto, em 1878, contra aqueles que denunciam de modo despei- 
tado o primitivismo semi-indígena da província de Corrientes, a que atribuem a tenaz fidelidade de alguns caudilhos políticos à facção liberal de Mitre, este responde com um documento que, de modo desafiador, intitula em guarani, a língua indígena ainda universalmente falada nessa província (Ayberecó-Quabà Catù, una provincia guarani). Se mesmo assim a recusa à visão polarizada que contrapóe civilizaçáo e barbárie permanece implícita, com o passar do tempo parece só ter ganho em energia.

Quanto à história que propóe, Mitre vê, na trajetória da Argentina, um avanço tanto para a tomada de consciência da sociedade rioplatense sob a figura da Nação, como para a institucionalizaçāo desta última no âmbito do constitucionalismo liberal e democrático a que a destina sua vocação original. Ela oferece a caução mais sólida para o patriotismo de Estado, e compreende-se bem por que um monumento historiográfico marcado por uma audaciosa originalidade de idéias tenha oferecido as noçōes básicas para a visáo do passado e do destino argentino difundida pela escola primária, instrumento de um esforço muito deliberado para improvisar uma consciência nacional para um país desfeito e refeito por uma avalanche imigratória sem paralelo na história universal.

Notas

1 Valentín Alsina. Notas al libro Civilización y Barbarie. In: Domingo Faustino Sarmiento, Facundo, Roberto Yahni (ed.), Madri, Cátedra, 1990, n.2, p.380.

2 loc.cit., p.399.

3 Em $A$ mi caballo; em Endecha del gaucho assumindo uma máscara que Sarmiento teria rechaçado para si, Gutiérrez vai mais longe, ao oferecer uma troca a um índio que se havia apropriado de seu cavalo, com seu Querida que es lucicnte como el oro. Ambas as poesias em Horacio Jorge Becco, Antologia de la poesía gauchesca, Madri, Aguilar, 1972, p.1635 e 1640.

4 El pato. Cuadro de costumbres. In: Becco, op.cit., p.1652.

5 Carta a Mariano de Sarratea, Buenos Aires, 29 de maio de 1855. In: Domingo F. Sarmiento, Obras Completas, t. XXIV, p.283, Buenos Aires, Luz del Día, 1951.

6 Bartolomé Mitre. Historia de Belgrano y de la Independencia Argentina, 5a ed., Buenos Aires, Biblioteca de la Nación, 1902, I, 6.

7 Mitre, op.cit., I, 9. 
8 Mitre, op.cit., $1,11$.

9 Mitre, op.cit., I, 9.

10 Discurso proferido em 25 de outubro de 1868 , no banquete popular que o povo de Chivilcoy the ofereceu, por motivo do feliz término de sua presidência constitucional. In: Bartolomé Mitre, Arengas, Buenos Aires, Casavalle, 1889.

11 Em anotaçăo em seu diário com data de 27 de setembro de 1843, Mitre assinala a semelhança entre o método expositivo adotado por Villemain em sua Histoire de Cromwell e "o modo que adotei para escrever a biografia de Artigas" (El diario de la juventud de Mitre, Buenos Aires, Institución Mitre, 1936, p.16).

12 O texto de Mitre publicado por Mariano de Vedia y Mitre, El manuscrito de Mitre sobre Artigas, Buenos Aires, La Facultad, 1937; citação da p.61.

13 D.F. Sarmiento. Facundo, p.91.

14 José María Ramos Mejía. Rosas y su tiempo, Buenos Aires, OCESA, 1952 [1907], cap.II: De dónde procede el tirano, I, p.65-93.

15 José C. Campobassi. Mitre y su época, Buenos Aires, Eudeba, 1980, p.17 e 22-23; Juan Angel Farini. Cronología de Mitre, 1821-1906, Buenos Aires, Institución Mitre, 1970.

16 Farini, op.cit., p.23.

17 Ver, sobre esse assunto, Natalio R. Botana. La libertad politica y su bistoria, Buenos Aires, Sudamericana-Instituto T. Di Tella, cap.VII: El debate sobre la guerra social, p.107-122.

Tulio Halperin Donghi, historiador, é professor do Departamento de História da Universidade da Califórina, Berkeley (EUA). É autor, entre outros, dos livros Historia Contemporanea da América Latina e Revolución y Guerra de Independencia en Argentina.

Tradução de Helena B. C. Pereira e Rena Signer. O original em espanhol Mitre y la formulación de una bistoria nacional para la Argentina - encontra-se à disposição do leitor no IEA-USP para eventual consulta. 